Páipéar Taighde Teicniúil

06/RT/14

Research Technical Paper

Attenuation bias, recall error and the housing wealth effect

Yvonne McCarthy and Kieran McQuinn 


\title{
Attenuation bias, recall error and the housing wealth effect
}

\author{
Yvonne McCarthy \& Kieran McQuinn*
}

March 2014

\begin{abstract}
The greater use of microeconomic and survey based data in addressing key financial stability related questions is a natural outcome of the recent financial crisis. Amongst other benefits, the use of such data enables a more precise understanding of the differing attitudes and responses of individual agents such as households to financial shocks. However, some difficulties can arise with the use, in particular, of survey data in this regard. In this paper we calculate measurement error in the house prices "recalled" by a representative sample of mortgaged Irish households and illustrate the degree of attenuation bias consequently introduced into estimates of housing wealth effects, when recall as opposed to actual house prices are used.
\end{abstract}

JEL classification: E21, C81, D12.

Keywords: Attenuation Bias, Recall Error, Consumption, House Prices.

*E-mail: yvonne.mccarthy@centralbank.ie and kieran.mcquinn@centralbank.ie. Address: Financial Stability Department, Central Bank of Ireland, PO Box 11517, Spencer Dock, North Wall Quay, Dublin 1, Ireland. Tel: +353 1 2246000. The views expressed in this paper are those of the authors and do not necessarily reflect those of the Central Bank of Ireland or the European Central Bank. We would like to thank Gerard O'Reilly, Central Bank of Ireland, for comments on an earlier draft. Any remaining errors are the responsibility of the authors. 


\section{Non-technical summary}

In this paper using two unique sources of data, we assess the accuracy with which Irish mortgaged households can remember the price they paid for their main residential property. We then assess the implications for estimates of the housing wealth effect when recall as opposed to actual house prices are used as an indicator of housing wealth.

Prudential data gathered for the main Irish financial institutions reveals the actual house price paid by most Irish mortgagees. In 2012, the Irish central bank conducted an income survey of mortgaged Irish households. In the survey, households were asked how much they had paid for their main residential dwelling (recall price). Thus, the accuracy of the recall price can be evaluated.

Significant error in the recall price has major implications for estimates of the housing wealth effect. An increasing number of micro based estimates of the housing wealth effect use the recall house price as an indicator of housing wealth. Where households are unable to accurately remember their house price on a systematic basis, the corresponding wealth effect estimates are likely to suffer from classical attenuation bias.

Our results suggest that Irish households have some difficulty in accurately remembering their house price with error measures indicating that most households are inclined to understate the true purchase price of their property. Accordingly, if the recall price was to be used as the indicator of Irish housing wealth, then the resulting wealth effect would be over 70 per cent less than that estimated with the actual price due to attenuation bias. The error itself would appear to be both a function of market conditions and individual household characteristics with the scale of house price movements being a particularly important factor. Therefore, survey data in housing markets which have experienced significant house price appreciation would appear to be most susceptible to this bias. 


\section{Introduction}

One of the many outcomes of the international crisis of 2007/08 is the need to use more microeconomic and survey based data in assessing key financial stability concerns. While there are a number of advantages to such data, a particular benefit is a more precise appreciation of the differing attitudes and responses of individual agents to key economic shocks. However, some difficulties can arise with the use of survey data in this regard. For example, it would appear that mortgaged households, especially in cases where house prices have witnessed large appreciation, have considerable difficulty in accurately recalling and objectively stating the monetary amount paid for assets such as housing.

While such a finding can have a number of different implications, one area where it can be most significant is in microeconomic assessments of the consumption housing wealth effect. The relationship between consumption and housing has a heightened importance given the strong inter-linkages between housing and the real economy revealed by the recent financial crisis. Understanding the economy-wide benefits of policy responses to the ensuing difficulties being experienced in some property markets is contingent on the wealth effect out of housing. ${ }^{1}$ While the question has been tackled using aggregate data for quite some time, the greater availability of survey data has resulted in an increased use of micro level information to address this question. In this paper, using a unique combination of two datasets, we highlight the bias, which is introduced into estimates of the housing wealth effect, when "recall" as opposed to actual house prices are used as indicators of housing wealth.

In examining for wealth effects, this bias is quite serious. For example, take a standard model, estimated with survey data, to quantify consumption-wealth effects such as: $C_{i}^{*}=\alpha+\beta P_{i}^{*}+\epsilon_{i}$ where $C_{i}^{*}$ is actual consumption, $P_{i}^{*}$ is actual house prices and $\alpha$ and $\beta$ are parameters to be estimated. If $P_{i}$ is the house price recalled for the survey by the household, and $P_{i}=P_{i}^{*}+\gamma_{i}$, where $\gamma_{i}$ is a random white noise error, it is well known that the larger the variance $\left(\sigma^{2}\right)$ of $\gamma_{i}$, the greater the degree of attenuation (towards zero) bias in $\beta$, causing the wealth effect to be underestimated. Clearly, in periods where house prices have changed considerably, the potential for $\sigma_{\gamma}^{2}$ to be non-trivial increases.

In this paper, using two unique datasets, we observe a significant degree of attenuation bias due to recall error amongst a representative sample of mortgaged Irish households. We use administrative information from mortgage loan-level data gathered on a regular basis by the Central Bank of Ireland for the three main Irish financial institutions. ${ }^{2}$ This dataset includes information on individual mortgage amounts, house prices at point of loan origination and mortgage repayment history.

This information is then combined with data from a representative household survey conducted in 2012/2013 on the mortgage books of the same institutions. ${ }^{3}$ In general the survey contains details such

\footnotetext{
${ }^{1}$ For example, debt relief has been cited as an option in markets experiencing significant negative equity and mortgage arrears.

${ }^{2}$ This data is collected for prudential purposes. The three institutions are Allied Irish Bank (AIB), Bank of Ireland (BOI) and Irish Life and Permanent (ILP).

${ }^{3}$ This survey was conducted between May 2012 and February 2013, and was designed to be representative of the mortgage book
} 
as the actual consumption, income, expenditure, savings and employment status of these households, however, survey participants are also asked about the value of their property at the time of purchase. Therefore, using unique identifiers and with the consent of the household, the information in the survey can be compared with the actual loan level data from the financial institutions thus enabling the recall error of the household to be measured.

Across countries, the mortgage market in Ireland stands out as an especially volatile case. Since the mid-1990s, the Irish property sector experienced, even by international standards, an unprecedented boom both in activity and price terms. In 2006, almost 90,000 residential units were constructed - just less than half the amount being built in the United Kingdom. By 2012, with the collapse in the market, less than 10,000 new units were supplied. House price increases were the largest across the OECD between 1995 and 2007, however, in 2012 prices had fallen by 50 per cent (in nominal terms) since their peak in 2007. Thus, the average Irish mortgagee will have witnessed substantial fluctuations in the value of their property over the past 10 years.

The presence of "recall" or measurement error in house prices could be one reason for the relatively disparate housing wealth effects found across certain studies. Bover (2005), for example, cites measurement error in housing wealth estimates as a potential reason for such results. ${ }^{4}$ If surveys are conducted, particularly across periods of significant house price movements, the associated wealth effect could be as much a function of the participant's recall accuracy as the underlying behavioural differences amongst households. We further explore this issue by also estimating the potential determinants of the actual recall error, examining both the influence of household characteristics and general housing market conditions.

The remainder of the paper is organised as follows; in the next section we describe the two datasets used in the analysis. In Section 3 we calculate the degree of recall error and consequent attenuation bias in an estimate of Irish housing wealth effects. A model is then estimated for the recall error of survey participants, while a final section offers some concluding comments.

\section{Overview of data}

Being able to quantify the actual recall error of survey participants is unique and arises out of two related but discrete datasets of the main Irish financial institutions. The first is a mortgage loan-level dataset collected by the Central Bank of Ireland as part of a prudential capital assessment review exercise of the Irish banking sector. Covering three Irish residential mortgage banks, which account for approximately 70 per cent of the loans issued in the Irish market, the dataset includes a snapshot of the entire residential mortgage book at June 2012. Amongst the variety of information collected on each mortgage loan are

\footnotetext{
of the three institutions AIB, BOI and ILP.

${ }^{4}$ See McCarthy and McQuinn (2013) for a recent review of micro-based housing wealth estimates.
} 
borrower and mortgage details from the point of loan origination as well as information on the value of the property on which the mortgage is secured. Table 1 provides an overview of the contents of the dataset. ${ }^{5}$

Complementing this information is a survey of the same residential loan book primarily designed to capture the current economic circumstances of Irish mortgagees. ${ }^{6}$ The survey, which was administered to over 2,000 households, all of whom are included in the loan-level dataset, was conducted over the period May 2012 to February 2013 and includes 97 questions which were asked of participants. While the survey mainly asks questions concerning relevant economic considerations such as consumption, income and employment status, participants are also asked as to the value of their property at the time of purchase.

Crucially, each individual's survey responses can be linked back to their corresponding mortgage information in the loan-level dataset, where the respondent gave permission for this linking to take place. ${ }^{7}$ By linking the two datasets in this manner, we are able to compare the actual house price reported in the loan level data with the survey response of the household. The work in this paper is based on a cleaned subsample of the linked dataset. An overview of the sample is presented in Table 2.

While the Irish property and mortgage market experienced significant change in the aftermath of the house price peak in 2007, by 2012, conditions (such as house price movements and changes in the number of households experiencing mortgage arrears) had stabilised. Therefore, survey responses obtained in that year are likely to be more representative of steady-state conditions in the Irish market than for any year since the mid-1990s.

\section{Estimates of recall error and attenuation bias}

The error associated with each household's recall of the price paid for their property can be defined as follows:

$$
\gamma_{i}=h_{i}^{A}-h_{i}^{R}
$$

where $\gamma$ is the recall error of household $i, h_{i}^{A}$ is the actual house price by the household, taken from the administrative loan-level dataset, and $h_{i}^{R}$ is the house price recalled by the household in the survey.

In Figure 1 we plot the distribution of both the error and the error as a percentage of actual house prices, while summary statistics of the errors are presented in Table 3. The error measures are skewed to the right indicating that most households are inclined to understate the true purchase price of their property. ${ }^{8}$ In

\footnotetext{
${ }^{5}$ Further information on the loan level dataset is available in Kennedy and Mclndoe-Calder (2011).

${ }^{6}$ This survey was commissioned by the Central Bank of Ireland and was carried out by ipsos MRBI on behalf of the bank. Further details on the survey are provided in the Appendix.

${ }^{7} 88$ per cent of the sample gave permission for this linking to take place.

${ }^{8}$ In a somewhat related piece of work, Benitez-Silva et al. (2010) use survey data from the Health and Retirement Study in the US to examine households' reported and actual property selling prices. They find that households tend to overestimate the selling price of their homes. Of course, recalling a recent selling price can involve a shorter recall time relative to recalling the original purchase
} 
Section 4 we examine the relationship between the recall error, household characteristics and housing market developments.

\subsection{Baseline model and comparison of wealth effects}

To demonstrate the attenuation effect of the recall error, we estimate a standard reduced-form specification relaying household consumption to the household's actual house price, income level and a series of controls for household characteristics. The model, which is also estimated in McCarthy and McQuinn (2013), can be summarised in a cross-sectional sense as follows, where lower case denotes logs:

$$
c_{i}=\beta_{0}+\beta_{1} h_{i}+\beta_{2} y_{i}+\sum_{j=3}^{n} \beta_{j} \phi_{i, j}+\epsilon_{i}
$$

$c_{i}$ is household $i^{\prime} s$ annual consumption on all goods and services (excluding mortgage and other debt repayments), $h_{i}$ is the current house price for household $\mathrm{i}, y_{i}$ is annual household income and $\phi_{i, j}$ are controls for household characteristics.

Note this specification is adopted to highlight the impact of bias when recall prices are used as the estimate of housing wealth. For example, we do not apply the more recent approach of Campbell and Cocco (2007) and Disney et al. (2010) who distinguish between expected and unexpected house price movements, although our findings would have implications for this distinction.

Table 4 provides a full overview of the independent variables used in the model. To control for household characteristics, we include variables capturing the number of people in the household as well as the gender, age, marital status, educational attainment and employment status of the main mortgage contributor. While our survey does not capture information on the euro amount of financial wealth holdings, we do know if households have savings or investments, so we include a dummy variable capturing this information in the regression. ${ }^{9}$

In the initial baseline estimation we use the actual house price $\left(h_{i}^{A}\right)$ as reported in the loan level data at the point of loan origination for $h_{i}$. In particular, we take this price and then "forecast" the data forward to the present using official regional house price data. ${ }^{10}$ The results are presented in Table 5. From the table, we can see that the coefficient on house prices is 0.134 , which, given the log-log estimation, is the elasticity of consumption with respect to housing wealth. As noted by McCarthy and McQuinn (2013), this estimate for the mean household is quite large when compared with other cross-country approaches. For example, Sierminska and Takhtamanova (2007), in a cross-country study, comment on the relatively high estimates of 0.123 and 0.135 for Canada and Italy respectively, so this result for the Irish market would

${ }^{9}$ Specifically, we generate a dummy variable that captures people who save regularly, receive any income from savings or investments, or who report that they have savings or investments that they can use in financial difficulties.

${ }^{10}$ See the Appendix for further details.
} 
appear to be at the high end of the international spectrum. ${ }^{11}$

Over the same sample, we now re-estimate (2), this time using the recall price from the survey, $\left(h_{i}^{R}\right)$, as opposed to the actual price in the loan level data for the household concerned. ${ }^{12}$ The results are in Table 6 . It is clear that the wealth effect $(0.038)$ has been reduced considerably with the re-estimated elasticity based on the recall price less than a third of the original effect. ${ }^{13}$

Given that we have the actual recall error, we also calculate the degree of attenuation bias with the familiar statistic:

$$
\operatorname{plim} \widehat{\beta_{1}}=\beta_{1}-\beta_{1} \frac{\sigma_{\gamma}^{2}}{\sigma_{h^{A}}^{2}+\sigma_{\gamma}^{2}} .
$$

where $\gamma$ is the recall error, i.e. the difference between the actual and recall price. Using (3) we calculate the attenuated coefficient as 0.040 - slightly larger than the 0.038 estimated in Table 6 . The difference may be explained by the violation of the assumption that classical measurement/recall error is uncorrelated with the true variable i.e. $\rho\left(h^{A}, \gamma\right)=0$. We find a correlation of 0.46 between the actual house price and the error, therefore, attributing all of the attenuation bias in Table 6 to measurement/recall error is an overstatement of the effect as some of the bias is due to the positive correlation. ${ }^{14}$ Nonetheless, the corrected estimate, based purely on measurement/recall error, is still only 30 per cent of the true wealth effect presented in Table 5. Clearly, using subjective estimates of house prices in the presence of such measurement error has significant implications for the associated wealth effect.

This degree of correction has significant implications when one considers the growing array of studies estimating housing wealth effects with survey data. Table 7 summarises some of these estimates along with their findings for wealth effects or the marginal propensity to consume (MPC) out of housing wealth. From the table, it can be seen that, in general, wealth effects would appear to be quite small based on both the MPC and the elasticity measures, however, the elasticity values can vary quite a lot. As can also be seen, many of the indicators of housing wealth used in these studies are self-reported house prices, thereby, potentially exposing the estimates to attenuation bias due to recall error. In the next section, we examine the nature of the measurement/recall error in more detail.

While some studies, such as Christelis et al. (2011), argue that the perceived rather than the actual price should be used in such consumption studies despite the fact that "in some cases the perceived losses

\footnotetext{
${ }^{11}$ Many housing wealth studies prefer to use the marginal propensity to consume (MPC) concept as a point of comparison. McCarthy and McQuinn (2013) argue for the use of the elasticity in the Irish context. The MPC associated with the 0.134 coefficient is 0.01 .

${ }^{12}$ Note the recall prices are also forecasted forward using the same official regional house price data.

${ }^{13}$ The associated MPC is now 0.004 .

${ }^{14}$ Portela et al. (2010) demonstrate that, in the presence of such correlation, the expression for attenuation bias should be expanded to $\operatorname{plim} \widehat{\beta_{1}}=\beta_{1}-\beta_{1} \frac{\sigma_{\gamma}^{2}}{\sigma_{h A}^{2}+\sigma_{\gamma}^{2}}-\beta_{1} \frac{\sigma h^{A}, \gamma}{\sigma^{2} h^{R}}$ where $h^{R}$ is the reported/recalled house price. The term $\frac{\sigma h^{A}, \gamma}{\sigma^{2} h^{R}}$ is added as it has implications for the estimate of the bias based on the degree of correlation between the measurement error $\gamma_{t}$ and the true house price $h_{t}^{A}$.
} 
might not reflect exactly the actual asset price movements", we argue that the actual price, where available, is always the relevant variable. If a mortgaged individual approaches a financial institution with a view to securing more funding for consumption purposes, it is the actual house price as opposed to the perceived price which would be considered for collateral purposes by the institution. Households may also display greater accuracy about their house price, when confronted by a consumption decision as opposed to a survey question.

\subsection{Robustness checks}

It is plausible that household consumption may respond to housing wealth at the beginning of the period of analysis rather than to the current value of housing wealth. Muellbauer (2007), for example, contains a discussion of this issue in considering appropriate consumption functions for estimating wealth effects. As a robustness check of the results in Tables 5 and 6 , we therefore re-run the regressions replacing both the current actual house price and the current survey house price with its equivalent one-year lag. The results are broadly unchanged; the coefficient on the actual house price lagged is 0.14 and 0.04 in the case of the survey house price.

A common criticism of the analysis of wealth effects is that it suffers from endogeneity bias, i.e. house prices and consumption could be related to expected future income rather than current income. To control for this, we replace household income in Tables 5 and 6 with its expected value. We follow the recent literature (Himmelberg et al. (2005) and Duca et al. (2011), for example) and proxy for expected income using the average of the lagged levels of income over the previous four year period (see A.2 in the Appendix for further details). The results, which are available in Tables 8 and 9 , reveal little differences relative to those reported in Tables 5 and 6.

\section{Modelling recall error}

To better understand the nature of the recall error, we plot the absolute value of the error amount against key variables in the dataset. In Figure 2, we plot the error against actual house prices and loan seasoning. The first chart shows a positive relationship between the error amount and the actual house price, suggesting that as house prices increase, the size of the recall error also increases. Loan seasoning captures the number of months since the loan was originated. Again, there appears to be some evidence of a positive relationship between the two; as loan seasoning increases, i.e. as the recall period lengthens, the size of the recall error tends to rise.

In Figure 3, we plot the distribution of the absolute value of the error across different groups in the sample. In general the differences in groups do not appear stark. However, a slightly higher proportion of 
the younger, more highly educated and employed groups make no error in recalling the purchase price of their property, relative to their counterparts. In the next section, we examine if these patterns remain in a multivariate setting when we control for the various factors that might impact the recall error.

\subsection{Recall price and price uncertainty}

Why might households have such difficulty in recalling the original price paid for their properties? While individual household characteristics will obviously impact on the recall performance, there may also be factors germane to the Irish property sector which affect households' performance in this regard. For example, the Irish market experienced very high house prices, particularly in the period up to 2007. Figure 4 presents a plot of actual Irish house prices from 1990 to 2012 - the sharp increase in prices from 1998 is readily apparent. Consequently, the scale of recall error could be a function of the initial house price.

Two further factors that may impact the recall error include the loan seasoning variable and the volatility of house price movements. On the one hand, the further back a household has to recall, and the more volatile house prices are over the period, the greater the potential for error in the house price subsequently cited. On the other hand, however, the stock of mortgages in Ireland is relatively young, especially when compared with other euro area countries. For example, up to 40 per cent of the current stock of Irish mortgages was issued between 2004 and 2007.

We examine the importance of these factors, along with other potential determinants of the household's recall error, in a more formal context by regressing the error on the original house price, $\left(h_{i}^{A}\right)$, an indicator of recent house price variance for the region in which the household resides, $\left(v_{a r}\right)$, a seasoning variable, $\left(\right.$ season $\left._{i}\right)$, denoting the number of months since the house was purchased, and the same set of household controls, $\left(\phi_{i, j}\right)$, used earlier in (equation 2). For the variance of house prices, we calculate the change in house prices in the household's county over the period 2006 quarter 4 to 2012 quarter $1 .{ }^{15}$ This results in the following model:

$$
\left|\gamma_{i}\right|=\alpha_{0}+\alpha_{1} h_{i}^{A}+\alpha_{2} \text { var }_{i}+\alpha_{3} \operatorname{season}_{i}+\Sigma_{j=4}^{n} \alpha_{j} \phi_{i, j}+\xi_{i}
$$

where $\left|\gamma_{i}\right|$ is the absolute value of the errors. As is evident from Figure $1, \gamma_{i}$ is not normally distributed, therefore, we use a quantile regression approach where the estimation takes place at the median as opposed to the mean. The results from the model are presented in Table 10.

The results show that a number of factors are important determinants of a respondent's recall error. Firstly, in terms of the variables capturing general market conditions, as expected, the actual house price has a positive impact on the scale of the error and this result is highly significant. Both the variance of

\footnotetext{
${ }^{15}$ The regional house price data were kindly supplied by Ronan Lyons of daft.ie and are available for each of the twenty six counties in the Irish Republic. The house prices are then matched to households from the particular county in question.
} 
house prices and loan seasoning have a positive impact on the recall error, however, these effects are not significant. In terms of household characteristics, it would appear that, even controlling for the seasoning effect, younger households are better able to recall the price paid for their property. Education is also important; individuals with a third level degree tended to report a recall error of about $€ 17,000$ less than their counterparts with a lower level of education. Finally, households with a higher level of income are associated with lower recall error.

Notwithstanding the importance of the original house price, the relevance of household specific factors in affecting the scale of the error would suggest that these findings are quite likely to be observed in other housing markets.

\section{Conclusions}

The interaction between the housing market and the broader economy has assumed an increased importance over the past 10 years. The fluctuations observed in house prices across certain OECD countries are likely to have had significant impacts on key macroeconomic variables such as consumption and investment. Consequently, an increasing number of studies, particularly, at a micro level, are concerned with estimating the consumption wealth effect out of housing.

Using unique survey and bank level prudential data, this paper has highlighted a potentially serious problem with certain survey based approaches to this issue. In the case of the Irish property market, it would appear that mortgaged households have considerable difficulty in accurately recalling the actual house price paid for their property. As most survey based approaches rely on a household's subjective view of its house price as an estimate of housing value, this may lead to significant measurement error and consequent attenuation bias in the estimated wealth effect.

In an Irish context, were the recall price to be used as the indicator of housing wealth, then the resulting wealth effect would be over 70 per cent less than that estimated with the actual price. The error itself would appear to be both a function of market conditions and individual household characteristics with the scale of house price movements being a particularly important factor. Therefore, survey data in housing markets which have experienced significant house price appreciation would appear to be most susceptible to this bias. 


\section{References}

[1] Attanasio O.P., Blow L., Hamilton R. and A. Leicester (2009), "Booms and busts: Consumption, house prices and expectations", Economica, Vol.76(301), pp. 20-50.

[2] Benitez-Silva, H., Selcuk, E., Heiland, F. and S. Jimenez-Martin (2010), "Using the health and retirement study to analyze housing decisions, housing values and housing prices", Cityscape: A Journal of Policy Development and Research, Vol.12(2), pp. 149-158

[3] Bostic R., Gabriel S. and G. Painter (2009), "Housing wealth, financial wealth and consumption: New evidence from micro data", Regional Science and Urban Economics, 39 (1), pp.79-89.

[4] Bover O. (2005), Wealth effects on consumption: Microeconometric estimates from the Spanish survey of household finances, Banco de España Working Paper 0522, Banco de España.

[5] Campbell J.Y. and J.F. Cocco (2007), "How do house prices affect consumption? Evidence from micro data", Journal of Monetary Economics, Vol.54 (3), pp.591-621.

[6] Christelis D., Georgarakos D. and T. Jappelli (2011), "Wealth shocks, unemployment shocks and consumption in the wake of the great recession", Centre for Studies in Economics and Finance (CSEF) Working paper no. 279.

[7] Disney R., Henley A. and D. Jevons (2003), House price shocks, negative equity and household consumption in the UK in the 1990s, unpublished.

[8] Disney R., Gathergood J. and A. Henley (2010), "House price shocks, negative equity and household consumption in the United Kingdom", Journal of the European Economics Association, Vol. 8, No. 6, pp. 1179-1207.

[9] Duca J.V., Muellbauer J. and A. Murphy (2011), "House prices and credit constraints: Making sense of the U.S. experience", Economic Journal, Vol. 121, pp. 533-551.

[10] Engelhardt G.V. (1996), "House prices and home owner saving behaviour", Regional Science and Urban Economics, Vol 26, pp.313-336.

[11] Himmelberg, C., Mayer C. and T. Sinai (2005), "Assessing high house prices: Bubbles, fundamentals and misperceptions", Journal of Economic Perspectives, Vol.19, Winter, 67-92.

[12] Kennedy, G. and T. Mclndoe Calder (2011), The Irish mortgage market: Stylised facts, negative equity and arrears, Central Bank of Ireland Research Technical Paper, No.12/RT/11.

[13] Lehnert, A. (2004), "Housing, consumption and credit constraints", Board of Governors of the Federal Reserve System, Finance and Economics Discussion Paper, No. 2004-63.

[14] Levin, L. (1998), "Are assets fungible? Testing the behavioral theory of life-cycle savings", Journal of Economic Behavior and Organization, Vol.36, pp. 59-83.

[15] McCarthy Y. and K. McQuinn (2013), Housing wealth and consumption: The case of a distressed property market, Central Bank of Ireland Research Technical Paper 06/RT/13.

[16] Muellbauer J. (2007), Housing, credit and consumer expenditure, Department of Economics, Oxford University working paper.

[17] Portela M., Alessie R. and C. Teulings (2010), "Measurement error in education and growth regressions," Scandanavian Journal of Economics 112(3), pp. 618-639.

[18] Sierminska E. and Y. Takhtamanova (2007), Wealth effects out of financial and housing wealth: Cross country and age group comparisons. Federal Reserve Bank of San Francisco Working Paper No. 2007-01, Federal Reserve Bank of San Francisco. 


\section{A Creation of Variables from Loan-Level Dataset}

The analysis in this paper relies, in part, on variables that are generated from the loan-level data (described previously). Here we detail precisely how these variables are calculated.

\section{A.1 Current house price}

The loan-level dataset includes the value of the house for which the original mortgage was taken out as well as the valuation date. The current house price $\left(P_{t}\right)$ is calculated as follows:

$$
P_{t}=P_{0} \times \frac{\bar{P}_{t}}{\bar{P}_{0}}
$$

where $P_{0}$ is the latest valuation of the property, and $\frac{\bar{P}_{t}}{\bar{P}_{0}}$ is the change in the average value of 'similar' properties between $t=0$ and $t=t$.

For loans originating from 2003 onwards, we use the CSO property price index to calculate the change in house prices over time. We match 'similar' properties on the basis of region (Dublin and non-Dublin) and type (house, apartment, other). For loans originating prior to 2003 we use the ptsb/ESRI house price index, which has a similar geographic breakdown as the CSO price index, but not a similar breakdown by property type. We therefore apply the ptsb/ESRI price index changes to all house-types.

\section{A.2 Expected Income}

The dataset that we use in the current analysis includes only the current gross income for each household in 2012. To calculate expected income in 2012 for household i, we follow the recent literature such as Himmelberg et al. (2005) and Duca et al. (2011) who argue (in the case of house prices) that expected values can be tracked by lagged values over the previous five and four years respectively. We therefore proxy for expected household income in 2012 using the average of the annual values over the 2008-2011 period.

Since our dataset does not include the value of household income in previous years, we calculate this by backcasting the current value of household income (in 2012) by the annual growth rate of household income in the region in which the household resides. These annual growth rates are available from the Irish Central Statistics Office (www.cso.ie) under the heading "Total Household Income by County and Region and Year".

\section{B The survey of mortgage holders}

The survey used in the present study was conducted by ipsos MRBI on behalf of the Central Bank of Ireland. The primary purpose of the survey was to collect up-to-date information on a mortgage holder's financial position, which could be appended to the mortgage loan level information held by the Central Bank for the three main Irish financial institutions (AIB, BOI and ILP). The survey was designed to be representative of the loan books of the three main institutions along five dimensions: lender type, borrower type, interest rate type, arrears and county of residence.

A two-stage sampling approach was used for the selection of cases for interview. In the first stage, representative clusters were formed from the loan-level data. In the second stage, clusters were randomly selected for interview. The total sample size achieved was 2,086 households, while the linked sample (those cases that permitted for their survey information to be linked back to their loan-level data at the Central Bank of Ireland) accounted for 88 per cent of this. The survey included questions in the following categories:

1. Mortgage background, including questions on the contributors to the mortgage repayment, the educational and employment characteristics of such contributors and details of unemployment where relevant.

2. Income and finances, including detailed questions on household income, recent income changes, details on household expenditures and questions on repayment difficulties where relevant.

3. Buy-to-lets and other financial holdings, details of institutions where borrowings and savings are held and questions on credit applications and rejections, and future expectations.

4. The mortgage arrears resolutions process (MARP), including questions on participation in the MARP process and the degree and nature of contact with the mortgage lender. 
Those households with an LTV ratio of greater than 100 are deemed to be in negative equity, while those with an LTV ratio of less than or equal to 100 are deemed to have positive equity in their property.

\section{B.1 Household Consumption}

To capture household consumption, respondents were presented with the following question:

Thinking of total household spending on all goods and services, but excluding mortgage and other debt repayments, how much would you say that your household spends in an average month? Please include spending on groceries, household utilities, clothing and footwear, travel expenses, childcare expenses, socialising, etc. 
Figure 1: Distribution of Recall Errors Across Sample
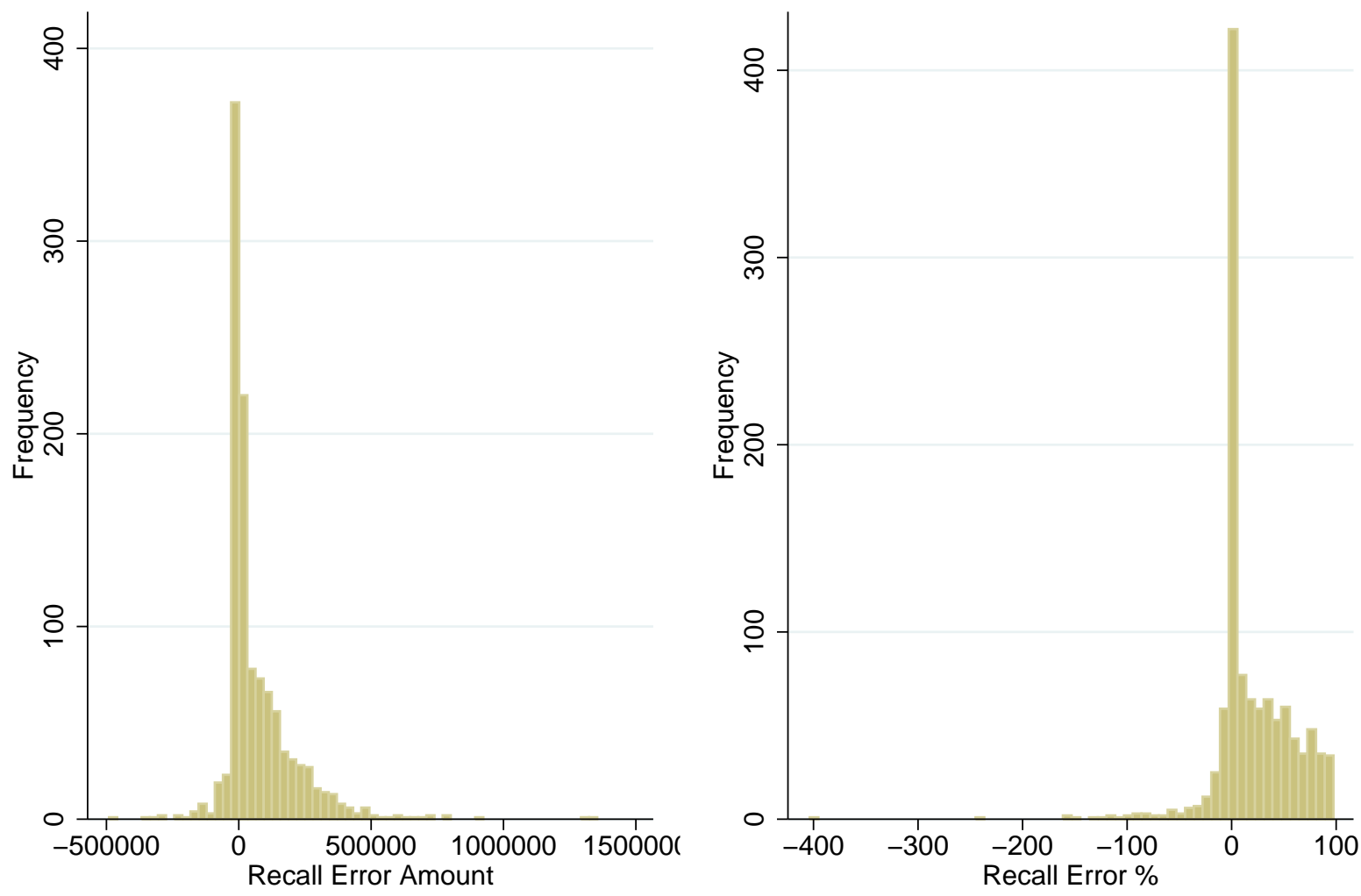
Table 1: Loan-Level Data Fields / Information Content

\begin{tabular}{|c|c|c|c|c|c|}
\hline Unit Identifier & Borrower & Property & Loan & Interest Rate & Performance \\
\hline $\begin{array}{l}\text { Bank } \\
\text { Borrower } \\
\text { Property } \\
\text { Loan }\end{array}$ & $\begin{array}{l}\text { Borrower Type } \\
\text { (FTB, BTL, etc.) } \\
\text { Income } \\
\text { Income Verified } \\
\text { Credit Quality }\end{array}$ & $\begin{array}{l}\text { Geographic Location } \\
\text { Property Type } \\
\text { New or Existing } \\
\text { Original Valuation } \\
\text { (and date) } \\
\text { Original LTV } \\
\text { Construction Year }\end{array}$ & $\begin{array}{l}\text { Origination Date } \\
\text { Original Loan Balance } \\
\text { Current Loan Balance } \\
\text { Loan Term } \\
\text { Loan Purpose } \\
\text { Current Repayment } \\
\text { Payment Type } \\
\text { Interest Rate Info. } \\
\text { Performance Info. }\end{array}$ & $\begin{array}{l}\text { Current Interest Rate } \\
\text { Interest Rate Type } \\
\text { Interest Rate Margin } \\
\text { Rate Revision Date }\end{array}$ & $\begin{array}{l}\text { Arrears Balance } \\
\text { (June-2012) } \\
\text { Arrears Balance } \\
\text { for Past } 12 \text { months } \\
\text { Collection Status } \\
\text { Modification / } \\
\text { Forbearance Flag }\end{array}$ \\
\hline
\end{tabular}

Notes: The above fields are not always populated in full. 
Table 2: Demographic and economic characteristics of the sample, \% of respondents unless otherwise stated

\begin{tabular}{|c|c|c|}
\hline Variable & & $\%$ \\
\hline \multirow[t]{5}{*}{ Age Group (years) } & $18-34$ & 16.6 \\
\hline & $35-44$ & 42.4 \\
\hline & $45-54$ & 28.1 \\
\hline & $55-64$ & 10.9 \\
\hline & $65+$ & 2.1 \\
\hline \multirow[t]{3}{*}{ Marital Status } & Married / Couple & 81.0 \\
\hline & Widowed/Separated & 6.4 \\
\hline & Single & 12.6 \\
\hline \multirow[t]{3}{*}{ Work Status } & Employed & 84.3 \\
\hline & Unemployed & 6.8 \\
\hline & Inactive & 8.9 \\
\hline \multirow[t]{3}{*}{ Education Status } & Low & 11.7 \\
\hline & Medium & 43.9 \\
\hline & High & 44.5 \\
\hline \multirow[t]{5}{*}{ Household Composition } & 1 Adult, 0 kids & 10.4 \\
\hline & 2 Adults, 0 kids & 14.9 \\
\hline & $3+$ Adults, 0 kids & 6.7 \\
\hline & 1+ Adults, with kids & 59.6 \\
\hline & Other & 8.4 \\
\hline \multirow[t]{4}{*}{ Median Financial Data $(€)$} & Income & 55,000 \\
\hline & Consumption & 15,300 \\
\hline & Current House Price & 180,278 \\
\hline & Mortgage Outstanding & 149,409 \\
\hline Negative Equity & $\%$ of Group & 41.8 \\
\hline Any Arrears & $\%$ of Group & 18.8 \\
\hline Has Savings/Investments & $\%$ of Group & 60.1 \\
\hline $\mathrm{N}$ & & 1,133 \\
\hline
\end{tabular}

Note: Low education includes individuals with a lower second level education or less. Medium education captures individuals with upper second level education and non-degree third level education. The high education category includes people with a third level degree. In terms of work status, the inactive category includes individuals who are retired, homemakers and students. 
Table 3: Summary statistics of recall error

\begin{tabular}{lcc}
\hline \hline & $\gamma(€)$ & $\frac{\gamma}{h^{A}}(\%)$ \\
& & \\
\hline Mean & & \\
Standard deviation & 139,960 & 18.9 \\
Skewness & 2.72 & 38.0 \\
Kurtosis & 18.36 & 19.16 \\
& & \\
\hline \hline
\end{tabular}

Table 4: Independent Variables

\begin{tabular}{|c|c|}
\hline Variable & Description \\
\hline$h_{i}$ & Logged house price (at June-2012) for household i. \\
\hline$y_{i}$ & Logged gross annual income for household i. \\
\hline male & Dummy variable indicating that the survey respondent is male. \\
\hline married & Dummy variable indicating that the survey respondent is married. \\
\hline HH size & $\begin{array}{l}\text { Continuous variable indicating the number of people in the } \\
\text { household. }\end{array}$ \\
\hline age $: 18-34$ & $\begin{array}{l}\text { Omitted category - captures survey respondents who are aged between } \\
18 \text { and } 34 \text { years. }\end{array}$ \\
\hline age $: 35-44$ & $\begin{array}{l}\text { Dummy variable indicating that the survey respondent is aged between } \\
35 \text { and } 44 \text { years. }\end{array}$ \\
\hline age $: 45-54$ & $\begin{array}{l}\text { Dummy variable indicating that the survey respondent is aged between } \\
45 \text { and } 54 \text { years. }\end{array}$ \\
\hline age $: 55-64$ & $\begin{array}{l}\text { Dummy variable indicating that the survey respondent is aged between } \\
55 \text { and } 64 \text { years. }\end{array}$ \\
\hline age : $65+$ & $\begin{array}{l}\text { Dummy variable indicating that the survey respondent is aged } 65 \text { years } \\
\text { or more. }\end{array}$ \\
\hline college education & $\begin{array}{l}\text { Dummy variable indicating that the survey respondent has a high level of } \\
\text { education (third level degree or above). }\end{array}$ \\
\hline unemployed & Omitted category - captures respondents who are unemployed. \\
\hline employed & Dummy variable indicating that the survey respondent is employed. \\
\hline retired/inactive & $\begin{array}{l}\text { Dummy variable indicating that the survey respondent is retired or inactive } \\
\text { (student, stay at home parent, etc.). }\end{array}$ \\
\hline saves/invests & Dummy variable indicating if the responding household has savings or investments. \\
\hline
\end{tabular}


Table 5: Baseline consumption regression - using actual house prices

\begin{tabular}{|c|c|c|c|}
\hline Variable & Coefficient & Standard Error & P-Value \\
\hline constant & 3.760 & 0.491 & 0.000 \\
\hline$h_{i}$ & 0.134 & 0.040 & 0.001 \\
\hline$y_{i}$ & 0.329 & 0.029 & 0.000 \\
\hline \multicolumn{4}{|l|}{ Additional Controls } \\
\hline male & -0.007 & 0.031 & 0.814 \\
\hline married & 0.066 & 0.049 & 0.179 \\
\hline HHsize & 0.117 & 0.015 & 0.000 \\
\hline age $: 35-44$ & 0.091 & 0.044 & 0.039 \\
\hline age $: 45-54$ & 0.115 & 0.047 & 0.014 \\
\hline age $: 55-64$ & 0.079 & 0.059 & 0.183 \\
\hline age $: 65+$ & 0.096 & 0.114 & 0.399 \\
\hline college education & -0.027 & 0.033 & 0.412 \\
\hline employed & 0.084 & 0.065 & 0.192 \\
\hline retired/inactive & 0.003 & 0.080 & 0.974 \\
\hline saves/invests & -0.013 & 0.033 & 0.687 \\
\hline $\mathrm{N}$ & & 1,133 & \\
\hline$F(13,1119)$ & & 38.55 & \\
\hline Prob $>F$ & & 0.000 & \\
\hline Adj. $R^{2}$ & & 0.3013 & \\
\hline
\end{tabular}

Note: ${ }^{* * \star}$ Significant at 1 per cent level; ${ }^{*}$ Significant at 5 per cent level; * Significant at 10 per cent level. Omitted categories for dummy variables are: age group 18-34 and unemployed. 
Table 6: Baseline consumption regression - using recall house prices

\begin{tabular}{|c|c|c|c|}
\hline Variable & Coefficient & Standard Error & P-Value \\
\hline constant & 4.718 & 0.361 & 0.000 \\
\hline$h_{i}$ & 0.038 & 0.022 & 0.085 \\
\hline$y_{i}$ & 0.346 & 0.029 & 0.000 \\
\hline \multicolumn{4}{|l|}{ Additional Controls } \\
\hline male & -0.009 & 0.031 & 0.772 \\
\hline married & 0.063 & 0.049 & 0.197 \\
\hline HHsize & 0.123 & 0.015 & 0.000 \\
\hline age $: 35-44$ & 0.100 & 0.044 & 0.024 \\
\hline age $: 45-54$ & 0.144 & 0.048 & 0.003 \\
\hline age $: 55-64$ & 0.116 & 0.060 & 0.054 \\
\hline age $: 65+$ & 0.141 & 0.114 & 0.215 \\
\hline college education & -0.027 & 0.034 & 0.424 \\
\hline employed & 0.081 & 0.065 & 0.210 \\
\hline retired/inactive & 0.014 & 0.080 & 0.866 \\
\hline saves/invests & -0.013 & 0.033 & 0.692 \\
\hline $\mathrm{N}$ & & 1,133 & \\
\hline$F(13,1119)$ & & 37.64 & \\
\hline Prob $>F$ & & 0.000 & \\
\hline Adj. $R^{2}$ & & 0.2962 & \\
\hline
\end{tabular}

Note: ${ }^{* * *}$ Significant at 1 per cent level; ${ }^{*}$ Significant at 5 per cent level; ${ }^{*}$ Significant at 10 per cent level. Omitted categories for dummy variables are: age group 18-34 and unemployed. 
Table 7: Summary of micro-survey based estimates of housing wealth effects

\begin{tabular}{|c|c|c|c|c|c|c|}
\hline Study & Country & Data Sources & Measure of Housing Wealth & Reference Period & MPC & Elasticity \\
\hline $\begin{array}{l}\text { Attanasio et al } \\
(2005)\end{array}$ & UK & $\begin{array}{l}\text { Family Expenditure } \\
\text { Survey (FES) }\end{array}$ & $\begin{array}{l}\text { Regional house prices from the Office of the } \\
\text { Deputy Prime Minister. Matched to households } \\
\text { on the basis of region. Specifications include } \\
\text { changes and levels of regional house prices. }\end{array}$ & $1978-2001$ & - & $0.04-0.21$ (varies with age) \\
\hline Bostic et al (2009) & US & $\begin{array}{l}\text { Survey of Consumer Fi- } \\
\text { nances (SCF) and the } \\
\text { Consumer Expenditure } \\
\text { Survey (pooled cross- } \\
\text { sections) }\end{array}$ & Self-reported home values. & $1989-2001$ & - & 0.06 \\
\hline Bover (2005) & Spain & $\begin{array}{l}\text { Survey of Spanish } \\
\text { Household Finances } \\
\text { (EFF) }\end{array}$ & $\begin{array}{l}\text { Self-reported home values (instrumented for in } \\
\text { various specifications). }\end{array}$ & 2002 & $\begin{array}{l}0.01 \text { to } 0.02 \text { (varies } \\
\text { with age) }\end{array}$ & - \\
\hline $\begin{array}{ll}\text { Campbell } & \text { and } \\
\text { Cocco (2005) }\end{array}$ & UK & FES Pseudo Panel & $\begin{array}{l}\text { Regional house prices from Nationwide. } \\
\text { Matched to households on the basis of region. }\end{array}$ & $1988-2000$ & - & $\begin{array}{l}\text { As large as } 1.7 \text { for older } \\
\text { households }\end{array}$ \\
\hline Disney et al (2003) & UK & $\begin{array}{l}\text { British Household } \\
\text { Panel Survey }\end{array}$ & $\begin{array}{l}\text { Regional house price variation, sourced from } \\
\text { Halifax Bank. }\end{array}$ & $1993-1999$ & $0.01-0.03$ & - \\
\hline Engelhardt (1996) & US & $\begin{array}{l}\text { Panel Study of Income } \\
\text { Dynamics (PSID) }\end{array}$ & $\begin{array}{l}\text { Self-reported home values less improvement } \\
\text { value. }\end{array}$ & 1984 and 1989 & $\begin{array}{l}0.03 \text { (median saver } \\
\text { household) or } 0.14 \\
\text { (mean saver house- } \\
\text { hold) }\end{array}$ & - \\
\hline Lehnert (2004) & US & $\begin{array}{l}\text { Panel Study of Income } \\
\text { Dynamics (PSID) }\end{array}$ & Self-reported home values. & $1968-1993$ & $\begin{array}{l}0.02-0.03 \text { (varies } \\
\text { with age) }\end{array}$ & $0.04-0.05$ (varies with age) \\
\hline Levin (1998) & US & $\begin{array}{l}\text { Retirement History Sur- } \\
\text { vey }\end{array}$ & $\begin{array}{l}\text { Net equity in home (self-reported home values } \\
\text { less outstanding mortgage). }\end{array}$ & $1969-1979$ & $\begin{array}{l}-0.006-0.05 \text { (varies } \\
\text { with credit con- } \\
\text { straints). However, } \\
\text { estimates are gen- } \\
\text { erally not significant. }\end{array}$ & - \\
\hline
\end{tabular}


Table 8: Robustness Check: Consumption regression - using actual house prices and expected income

\begin{tabular}{|c|c|c|c|}
\hline Variable & Coefficient & Standard Error & P-Value \\
\hline constant & 3.742 & 0.492 & 0.000 \\
\hline$h_{i}$ & 0.134 & 0.040 & 0.001 \\
\hline expected $y_{i}$ & 0.330 & 0.029 & 0.000 \\
\hline \multicolumn{4}{|l|}{ Additional Controls } \\
\hline male & -0.006 & 0.031 & 0.836 \\
\hline married & 0.067 & 0.049 & 0.172 \\
\hline HHsize & 0.116 & 0.015 & 0.000 \\
\hline age $: 35-44$ & 0.091 & 0.044 & 0.039 \\
\hline age $: 45-54$ & 0.116 & 0.047 & 0.014 \\
\hline age $: 55-64$ & 0.083 & 0.059 & 0.161 \\
\hline age $: 65+$ & 0.096 & 0.114 & 0.398 \\
\hline college education & -0.029 & 0.033 & 0.387 \\
\hline employed & 0.084 & 0.065 & 0.193 \\
\hline retired/inactive & 0.002 & 0.080 & 0.981 \\
\hline saves/invests & -0.012 & 0.033 & 0.710 \\
\hline $\mathrm{N}$ & & 1,131 & \\
\hline$F(13,1117)$ & & 38.56 & \\
\hline Prob $>F$ & & 0.000 & \\
\hline Adj. $R^{2}$ & & 0.3017 & \\
\hline
\end{tabular}

Note: ${ }^{* * \star}$ Significant at 1 per cent level; ${ }^{*}$ Significant at 5 per cent level; * Significant at 10 per cent level. Omitted categories for dummy variables are: age group 18-34 and unemployed. 
Table 9: Robustness Check: Consumption regression - using recall house prices and expected income

\begin{tabular}{|c|c|c|c|}
\hline Variable & Coefficient & Standard Error & P-Value \\
\hline constant & 4.694 & 0.362 & 0.000 \\
\hline$h_{i}$ & 0.039 & 0.022 & 0.082 \\
\hline expected $y_{i}$ & 0.347 & 0.029 & 0.000 \\
\hline \multicolumn{4}{|l|}{ Additional Controls } \\
\hline male & -0.008 & 0.031 & 0.794 \\
\hline married & 0.065 & 0.049 & 0.186 \\
\hline HHsize & 0.122 & 0.015 & 0.000 \\
\hline age $: 35-44$ & 0.100 & 0.044 & 0.024 \\
\hline age $: 45-54$ & 0.145 & 0.048 & 0.002 \\
\hline age : $55-64$ & 0.120 & 0.060 & 0.046 \\
\hline age $: 65+$ & 0.141 & 0.114 & 0.216 \\
\hline college education & -0.029 & 0.034 & 0.397 \\
\hline employed & 0.081 & 0.065 & 0.210 \\
\hline retired/inactive & 0.013 & 0.080 & 0.873 \\
\hline saves/invests & -0.012 & 0.033 & 0.717 \\
\hline $\mathrm{N}$ & & 1,131 & \\
\hline$F(13,1119)$ & & 37.67 & \\
\hline Prob $>F$ & & 0.000 & \\
\hline Adj. $R^{2}$ & & 0.2967 & \\
\hline
\end{tabular}

Note: ${ }^{* *}$ Significant at 1 per cent level; ${ }^{* *}$ Significant at 5 per cent level; * Significant at 10 per cent level. Omitted categories for dummy variables are: age group 18-34 and unemployed. 
Table 10: Recall error regression estimates

\begin{tabular}{|c|c|c|c|}
\hline Variable & Coefficient & Standard Error & P-Value \\
\hline constant & -20032.450 & 50673.200 & 0.693 \\
\hline$h_{i}^{A}$ & 0.349 & 0.033 & 0.000 \\
\hline $\operatorname{var}_{i}$ & 747.749 & 768.669 & 0.331 \\
\hline season $_{i}$ & 76.322 & 122.226 & 0.532 \\
\hline$y_{i}$ & -0.285 & 0.146 & 0.051 \\
\hline \multicolumn{4}{|l|}{ Additional Controls } \\
\hline male & -1785.884 & 9526.473 & 0.851 \\
\hline married & -13338.850 & 14858.090 & 0.370 \\
\hline HHsize & 4269.061 & 4554.730 & 0.349 \\
\hline age $: 35-44$ & 17361.050 & 13714.440 & 0.206 \\
\hline age $: 45-54$ & 54002.740 & 14975.960 & 0.000 \\
\hline age $: 55-64$ & 54165.580 & 18980.860 & 0.004 \\
\hline age $: 65+$ & 57031.960 & 34928.940 & 0.103 \\
\hline college education & -17123.500 & 10224.720 & 0.094 \\
\hline employed & 10062.950 & 18955.840 & 0.596 \\
\hline retired/inactive & 14237.080 & 24183.870 & 0.556 \\
\hline $\mathrm{N}$ & & 1,132 & \\
\hline Pseudo $\mathrm{R}^{2}$ & & 0.1166 & \\
\hline
\end{tabular}

Note: ${ }^{* * *}$ Significant at 1 per cent level; ${ }^{* *}$ Significant at 5 per cent level; * Significant at 10 per cent level. Omitted categories for dummy variables are: age group 18-34 and unemployed. 
Figure 2: Error Amount

by Actual House Price and Loan Seasoning
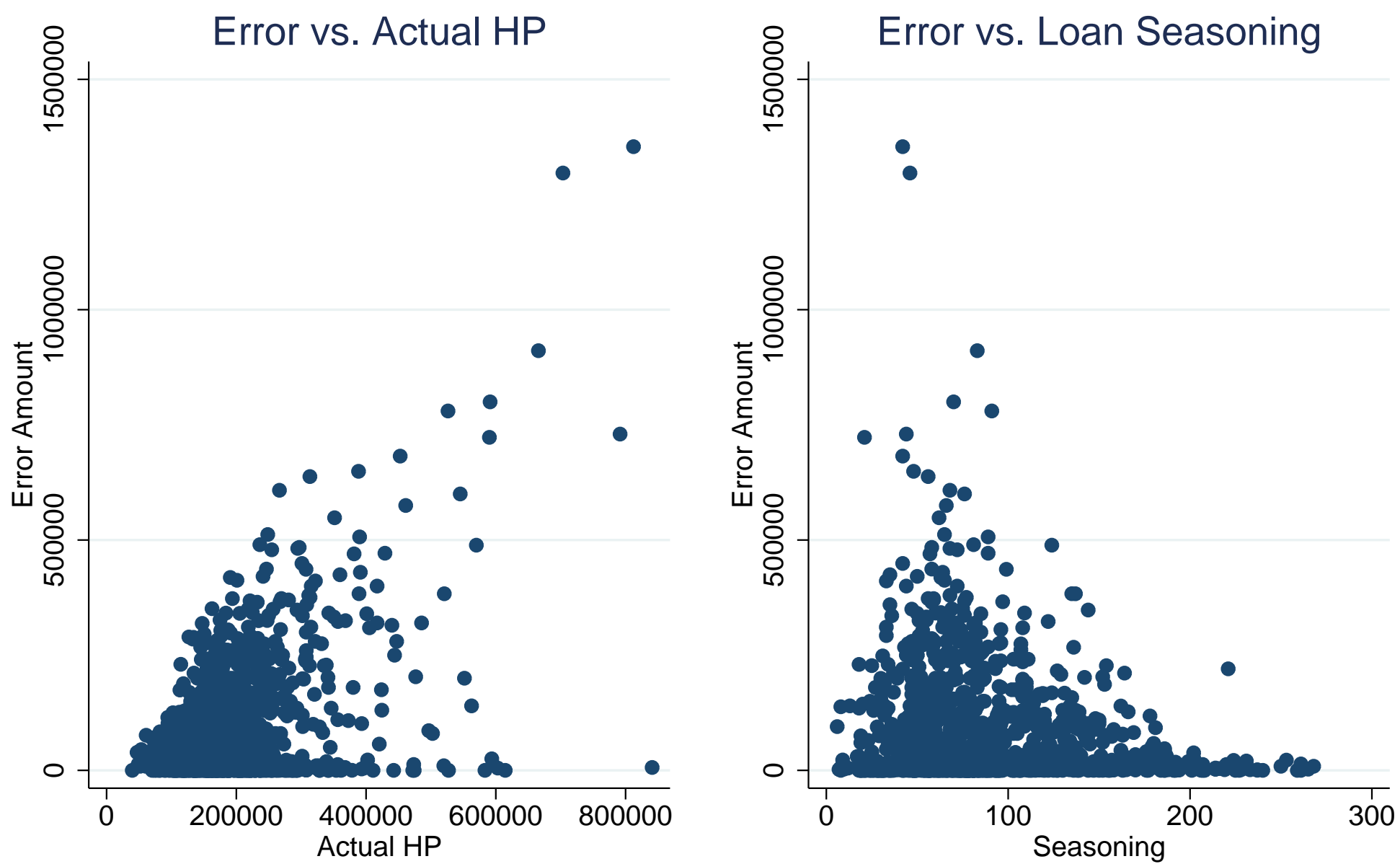


\section{Figure 3: Error Amount, by Groups}
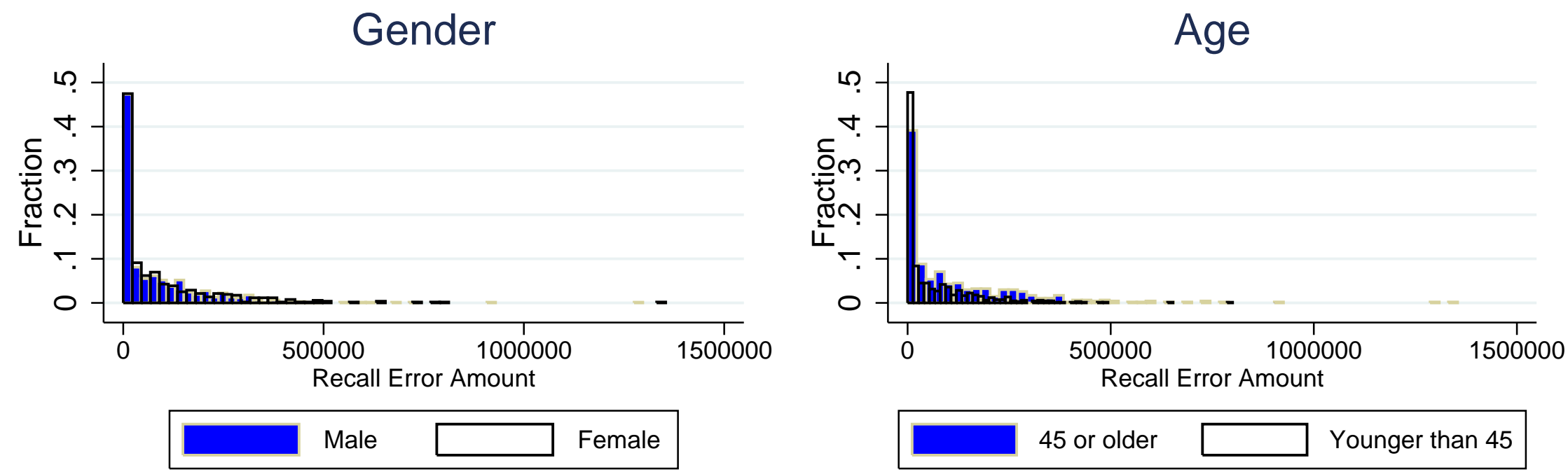

\section{Education}
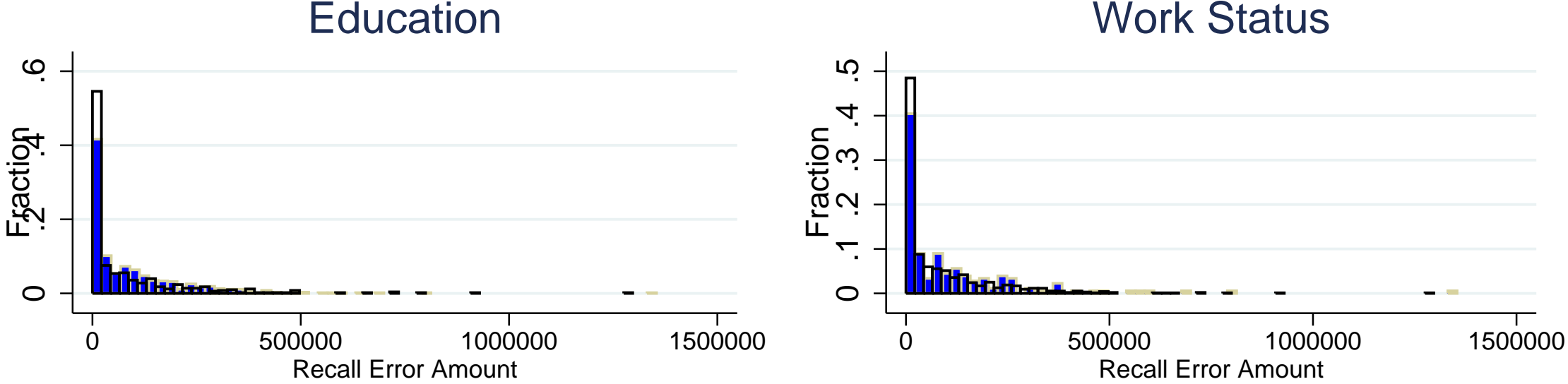

No College Educ.

College Educ. 
Figure 4

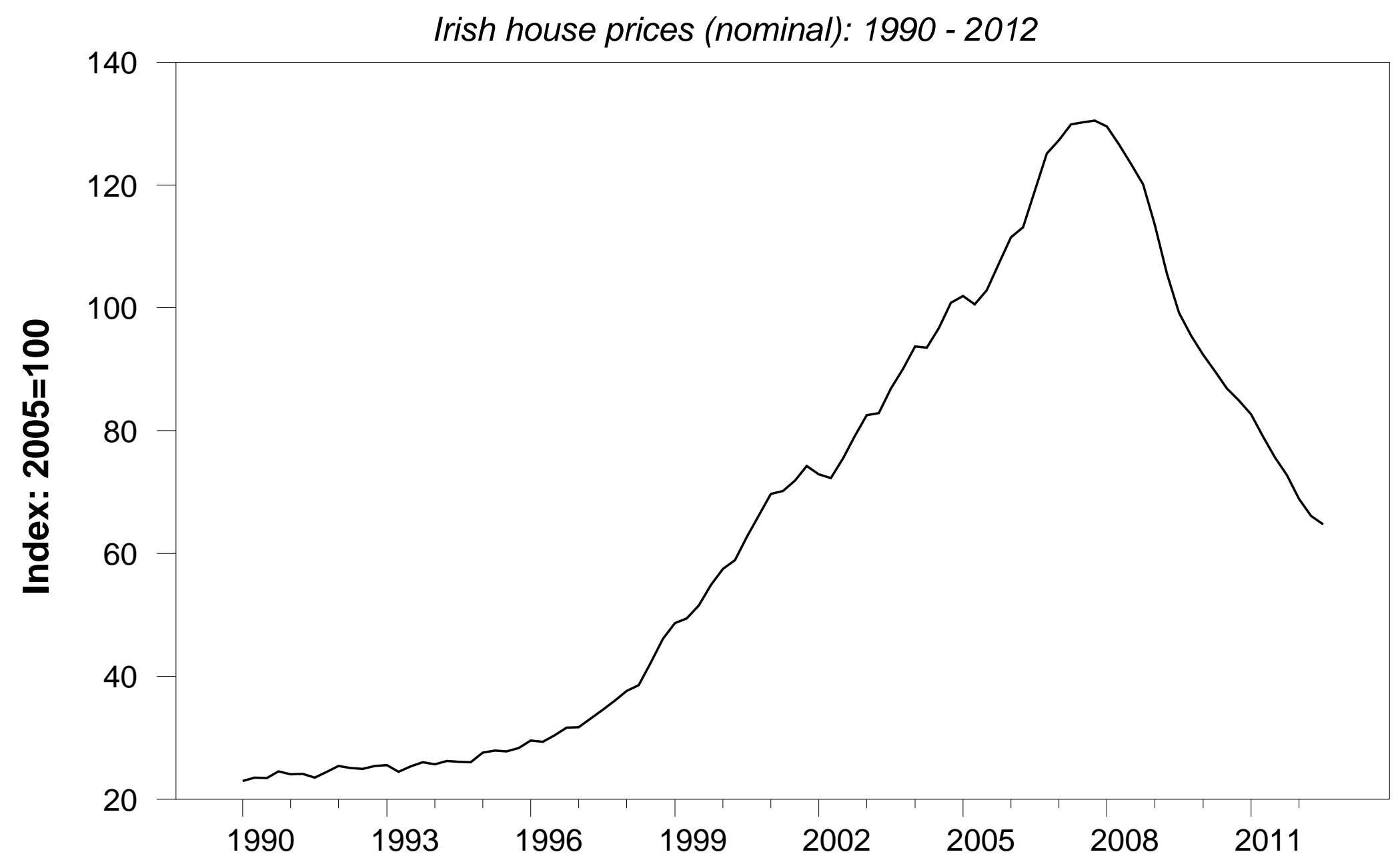

